\title{
Genetic differences between Mestizo populations of Bolivia and Peru
}

Diferencias genéticas entre poblaciones mestizas de Bolivia y Perú

Différences génétiques entre les populations métisses de Bolivie et du Pérou

\section{Jorge Cervantes}

\section{(2) OpenEdition}

Journals

Electronic version

URL: http://journals.openedition.org/bifea/6500

DOI: $10.4000 /$ bifea. 6500

ISSN: 2076-5827

\section{Publisher}

Institut Français d'Études Andines

Printed version

Date of publication: 1 April 2003

Number of pages: $213-222$

ISSN: 0303-7495

\section{Electronic reference}

Jorge Cervantes, "Genetic differences between Mestizo populations of Bolivia and Peru », Bulletin de I'Institut français d'études andines [Online], 32 (1) | 2003, Online since 08 April 2003, connection on 08 December 2020. URL : http://journals.openedition.org/bifea/6500; DOI : https://doi.org/10.4000/ bifea. 6500

\section{(@) $(\mathcal{Q} \Theta \Theta$}

Les contenus du Bulletin de l'Institut français d'études andines sont mis à disposition selon les termes de la licence Creative Commons Attribution - Pas d'Utilisation Commerciale - Pas de Modification 4.0 International. 


\title{
GENETIC DIFFERENCES BETWEEN MESTIZO POPULATIONS OF BOLIVIA AND PERU
}

\author{
Jorge CERVANTES*
}

\begin{abstract}
Data on the genetic background of Peruvian and Bolivian populations is still scarce. Studies have shown that mestizos (i.e. mixed, but of predominantly Native American ancestry) present several HLA alleles originally described in genetically isolated Amerindian tribes, and that Peruvian and Bolivian mestizos are closely genetically related.

Using Reverse Line Blot Assay, HLA typing for Class I (HLA-A, HLA-B, and HLA-Cw) as well as for Class II (HLA-DRB1 and HLA-DQB1) alleles was performed in 57 Bolivian mestizos. Subjects came mainly from La Paz (the main city in the Bolivian Andes) and three other important cities located in the Bolivian Central Valley (Sucre, Tarija and Tupiza).

Comparison of the allele frequencies of Bolivian mestizos with available data from the literature from Peruvian mestizos, revealed that Class I HLA-Cw*01, and $\mathrm{B} * 40$ alleles were higher in the Peruvian mestizo group (Chi-sq $=4,87 \mathrm{p}<0,05$; and chi-sq $=7,56 \mathrm{p}<0,01$ respectively). Regarding Class II alleles, HLA-DRB1*1101 and DRB1*1302 alleles were higher in Peruvian mestizos (Chi-sq $=5,12 \mathrm{p}<.05 ;$ chi-sq $=3,8 \mathrm{p}=0.05$ respectively), while HLA-DQB $1 * 0402$ was significantly higher in Bolivian mestizos (Chi-sq $=47,2 \mathrm{p}<.0001$ ).

Differences in allele frequencies, and the absence or presence of certain alleles in either group could be due to a higher grade of admixture with Andean ethnic groups in the mestizos from Bolivia and/or less rural traits and more white (Caucasian) admixture in the Peruvian mestizos reported in the literature.

These findings may have an impact regarding efficacies of modern forms of immunization (DNA vaccines) in Andean population, as well as in the identification of groups at risk for certain medical conditions.
\end{abstract}

Key words: Mestizo, HLA, allele,DNA.

\section{DIFERENCIAS GENÉTICAS ENTRE POBLACIONES MESTIZAS DE BOLIVIA Y PERÚ}

\section{Resumen}

Existe escasa información acerca del fondo genético de las poblaciones de Perú y Bolivia. Estudios han mostrado que los mestizos presentan varios alelos del sistema mayor de histocompatibilidad originalmente descritos en tribus amerindias genéticamente aisladas, y que los mestizos de Perú y Bolivia están genéticamente cercanamente relacionados. u.ac.jp

*Department of Virology. KagoshimaUniversity, Japan.E-mail:jorge-c@ @m3.kufm.kagoshima- 
Mediante la técnica de transferencia de línea reversa, se realizó la tipificación de alelos de histocompatibilidad de Clase I (HLA-A, HLA-B, HLA-Cw) así como de Clase II (HLA-DRB1 y HLA-DQB1) en 57 mestizos bolivianos. Los sujetos provinieron mayormente de La Paz (la ciudad principal en los Andes Bolivianos), además de otras tres ciudades importantes situadas en el Valle Central Boliviano (Sucre, Tarija y Tupiza).

La comparación de la frecuencia de los alelos de los mestizos bolivianos con datos disponibles de la literatura acerca de mestizos peruanos, reveló que los alelos de Clase I HLA$\mathrm{Cw} * 01$, y B*40 se encontraban en mayor proporción en el grupo de mestizos peruanos (Chicuadrado $=4.87 \mathrm{p}<0,05 ; \mathrm{y}$ chi-cuadrado $=7,56 \mathrm{p}<0,01$ respectivamente). Con respecto a los alelos de clase II, HLA-DRB $1 * 1101$ y DRB $1 * 1302$ se encontraron en mayor frecuencia en los mestizos peruanos (Chi-cuad $=5,12 \mathrm{p}<.05 ; \mathrm{y}$ chi-cuad $=3,8 \mathrm{p}=0.05$ respectivamente), mientras que el alelo HLA-DQB1*0402 fue significativamente mayor en los mestizos bolivianos (Chicuad $=47,2 \mathrm{p}<.0001)$.

Las diferencias en las frecuencias de alelos encontradas, y la ausencia o presencia de algunos alelos en cualesquiera de los grupos, puede deberse a un grado mayor de mixtura en los mestizos de Bolivia con grupos étnicos andinos, y/o menos rasgos rurales y mayor mixtura caucásica en los mestizos peruanos reportados en la literatura.

Estos hallazgos podrían tener un impacto con respecto a la eficacia de formas modernas de inmunización a través de vacunas de ADN en población andina, y en la identificación de riesgo para ciertas condiciones médicas.

Palabras claves: Mestizo, histocompatibilidad, alelo, ADN.

\section{DIFFÉRENCES GÉNÉTIQUES ENTRE LES POPULATIONS MÉTISSES DE BOLIVIE ET DU PÉROU}

\section{Résumé}

Il y a peu d'information à propos du fond génétique des populations du Pérou et de la Bolivie. Des études ont montré que les métisses (i.e. Mixe, dont la prédomination est d'ascendance native américaine) montrent plusieurs allèles du système majeur d'histocompatibilité, initialement décrites chez des tribus amérindiennes génétiquement isolées, et que les métisses du Pérou et de la Bolivie sont étroitement liés génétiquement.

Au moyen de la technique de transférence en ligne réversée, on a pu réaliser la typification des allèles d'histocompatibilité de Classe I (HLA-A, HLA-B, HLA-Cw) aussi bien que ceux de Classe II (HLA-DRB1 and HLA-DQB1) sur 57 métisses boliviens. La plupart des sujets sont originaires de La Paz (principale ville des Andes boliviennes), ainsi que de trois autres villes importantes situées dans le Vallée Centrale Bolivienne (Sucre, Tarija et Tupiza).

La comparaison des fréquences des allèles des métisses boliviens avec ceux qui étaient disponibles sur les métisses péruviens, révèle que les allèles de Classe I HLA-Cw*01, et B*40 étaient plus élevés que sur le groupe de métisses péruviens (Chi-carré $=4,87 \mathrm{p}<0,05$; et chicarré $=7,56 \mathrm{p}<0,01$ respectivement). En ce qui concerne les allèles de classe II, HLA-DRB $1 * 1101$ et DRB $1 * 1302$, on en trouve plus fréquemment chez les métisses péruviens (Chi-carré $=5,12$ $\mathrm{p}<.05$; et chi-carré $=3,8 \mathrm{p}=0,05$ respectivement), alors que l'allèle HLA-DQB $1 * 0402$ était présent de façon plus significative chez les métisses boliviens (Chi-carré $=47,2$ p<.0001).

Les différences de fréquences des allèles trouvés, et l'absence ou la présence de quelques uns dans un groupe ou dans un autre, peut peut-être s'expliquer par un degré plus grand d'assortiment entre les métisses de Bolivie avec des groupes étniques andins, et/ou moins de traits à caractère rural et un plus grand assortiment de type caucasien chez les métisses péruviens rapportés dans la littérature. 
Ces découvertes pourraient avoir un impact en ce qui concerne l'efficacité de moyens d'immunisation modernes grâce aux vaccins d'ADN sur la population andine, et aussi en ce qui concerne l'identification de groupes à risque pour certaines conditions médicales.

Mots clés : Métisses, histocompatibilité, allèle, AND.

\section{INTRODUCTION}

Bolivia and Peru are neighboring South American Andean countries, sharing geographically the Altiplane and the Titicaca Lake (the highest lake in the world). Besides its geographic connection, cultural, ethnic and linguistic liaisons are present between both countries since the Inca Empire times.

Bolivia is one of the less populated countries in South America. Ethnic groups present in this country are: Quechua, Aymara, Mestizo, White, and Guarani. Previous reports have shown that Peruvian and Bolivian mestizo (i.e Mixed, of predominantly Native American Ancestry) are closely genetically related (de Pablo et al., 2000).

The human major histocompatibility complex (MHC) (termed HLA, for human leukocyte antigen) comprises a family of genes that control immune response to pathogens, graft acceptance or rejection (i.e. transplant "compatibility"), and tumor surveillance. Its importance has been recognized by the award of the Nobel Prize to Doherty and Zinkernagel in 1996. The MHC has been the focus of interest since the past decades, as its extensive polymorphism defines a unique genetic fingerprint of an individual $A$ fs immune system, that is why HLA typing applications are not confined to medicine and medical research (transplantation, and disease association), it is also useful in paternity testing, in which is an informative tool for excluding parentage in cases of false accusation (Bryant, 1994), and in molecular anthropology giving scientific support to generate hypothesis about patterns of human evolution and migration (Apple \& Erlich, 1996) .

Originally described by Goran in the 1930's, the MHC is encoded on the short arm of the chromosome 6 in humans and includes at least 200 genes. The complex is divided into three regions: Class II (HLA-DR, -DP and -DQ genes), class III (which includes genes encoding complement and tumor necrosis factor), and class I (HLA-A, -B, -C, -E, -H, -G and -F genes) (Moss et al., 1999).

Data on the genetic background of Peruvian and Bolivian populations is somehow still scarce. As studies have shown that mestizos (i.e. Mixed, of predominantly Native American Ancestry)(IHWG, 2002), are closely genetically related, we performed HLA class I and HLA class II allele typing in 57 Bolivian mestizos and compared their allele frequencies with data available from the literature from Peruvian mestizos (de Pablo et al., 2000; Castro et al., 2001; Seclen, 1996).

\section{SUBJECTS AND METHODS}

\section{1. Subjects}

Fifty seven (57) Bolivian mestizosmestizos. Most of the study subjects came from La Paz, the main city in the Bolivian Altiplane (located between 3150 and 4100 meters 
above the sea level), and from three other important cities in the Bolivian Central Valley (Sucre, Tarija and Tupiza).

\section{2. Samples}

After obtaining informed consent, peripheral blood samples were collected. Sera and peripheral blood lymphocytes (PBL) were separated and cryopreserved as described elsewhere (Katahira et al., 1995)

\section{3. HLA typing}

Chromosomal DNA was extracted from the cryopreserved peripheral blood lymphocytes by the guanidine-HCl procedure (SMITEST EX-R\&D, Sumitomo Metal Industry Japan). HLA typing for Class I (HLA-A, HLA-B, HLA-Cw) as well as Class II (HLA-DRB1 and HLA-DQB1) alleles was performed by a PCR-reverse line blot assay (Bugawan et al.,1994) (Dynal RELI ${ }^{\mathrm{TM} S S O}$, Dynal Biotech Ltd, U.K.).

\section{4. Statistical Analysis}

The Chi-square or Fisher's exact test, where appropiate, was used for comparison of allele frequencies between Bolivian and Peruvian mestizos. Tests were run using SPSS (Statistical Package for the Social Sciences) software, version 7.5 (SPSS Inc. 1989-1996).

\section{RESULTS}

Comparison of the allele frequencies of Bolivian mestizos with available data from Peruvian mestizos (de Pablo et al., 2000; Castro et al., 2001; Seclen, 1996), revealed that Class I HLA-Cw*01, and B*40 alleles were higher in the Peruvian mestizo group $($ Chi-sq $=4,87 \mathrm{p}<0,05 ;$ and chi-sq $=7,56 \mathrm{p}<0,01$ respectively) $($ Table 1$)$. Regarding Class II alleles, HLA-DRB1*1101 and DRB1*1302 alleles were higher in Peruvian mestizos (Chi-sq $=5,12 \mathrm{p}<.05$; chi-sq $=3,8 \mathrm{p}=0,05$ respectively), while HLADQB1*0402 was significantly higher in Bolivian mestizos (Chi-sq $=47,2 \mathrm{p}<.0001$ ) (Tables 2 and 3).

\section{DISCUSSION}

Some indigenous populations (Native Americans for example) show a very restricted diversity of HLA alleles, which reflects a population bottleneck in the founding of these groups (Apple \& Erlich, 1996). In contrast, African populations contain the most diverse set of HLA class II alleles and haplotypes, (i.e. groups of closely linked alleles) consistent with the hypothesis that modern humans arose from an ancestral African population.

It has been reported that Peruvian and Bolivian mestizos are closely genetically related (de Pablo et al., 2000). Even though most of South American countries like Peru 
Table 1 - HLA Class I allele frequencies in Peruvian (Arequipa) and Bolivian mestizos.

\begin{tabular}{|c|c|c|c|c|}
\hline \multirow[b]{2}{*}{ HLA Class I alleles } & \multicolumn{2}{|c|}{$\begin{array}{c}\text { Peruvian mestizo } \\
(\mathrm{n}=148) \\
296 \text { alleles }\end{array}$} & \multicolumn{2}{|c|}{$\begin{array}{c}\text { Bolivian mestizo } \\
(\mathrm{n}=57) \\
114 \text { alleles }\end{array}$} \\
\hline & $\mathrm{n}$ & AF (\%) & $\mathrm{n}$ & AF $(\%)$ \\
\hline A*01 & 12 & 4.1 & 2 & 1.8 \\
\hline $\mathrm{A} * 02$ & 162 & 54.5 & 54 & 47.4 \\
\hline$A^{*} 03$ & 12 & 4.0 & 6 & 5.3 \\
\hline A*11 & 13 & 4.4 & 0 & 0.0 \\
\hline$A * 23$ & 6 & 2.0 & 3 & 2.6 \\
\hline A*24 & 31 & 10.4 & 13 & 11.4 \\
\hline$A * 26$ & 3 & 1.0 & 5 & 4.4 \\
\hline$A * 29$ & 8 & 2.7 & 2 & 1.8 \\
\hline $\mathrm{A} * 30$ & 5 & 1.7 & 2 & 1.8 \\
\hline$A * 31$ & 12 & 4.0 & 10 & 8.8 \\
\hline$A * 32$ & 6 & 2.0 & 1 & 0.9 \\
\hline$A * 36$ & 1 & 0.3 & 0 & 0.0 \\
\hline$A * 66$ & 2 & 0.7 & 0 & 0.0 \\
\hline$A * 68$ & 20 & 6.8 & 15 & 13.2 \\
\hline A*69 & 1 & 0.3 & 1 & 0.9 \\
\hline$A * 80$ & 2 & 0.7 & 0 & 0.0 \\
\hline $\mathrm{Cw}^{* 01}$ & 41 & $13.3^{\mathrm{a}}$ & 9 & 7.9 \\
\hline $\mathrm{Cw} * 02$ & 4 & 1.4 & 2 & 1.8 \\
\hline $\mathrm{Cw} * 03$ & 27 & 8.8 & 9 & 7.9 \\
\hline $\mathrm{Cw} * 04$ & 115 & 37.4 & 44 & 38.6 \\
\hline $\mathrm{Cw}^{*} 05$ & 10 & 3.4 & 2 & 1.8 \\
\hline $\mathrm{Cw} * 06$ & 7 & 2.4 & 5 & 4.4 \\
\hline $\mathrm{Cw} * 07$ & 34 & 11.1 & 16 & 14.0 \\
\hline $\mathrm{Cw} * 08$ & 24 & 7.9 & 11 & 9.6 \\
\hline $\mathrm{Cw} * 12$ & 6 & 2.0 & 3 & 2.6 \\
\hline $\mathrm{Cw} * 15$ & 21 & 6.7 & 12 & 10.5 \\
\hline $\mathrm{Cw} * 16$ & 6 & 2.0 & 1 & 0.9 \\
\hline$B * 05$ & 0 & 0.0 & 7 & 6.1 \\
\hline $\mathrm{B} * 07$ & 7 & 2.4 & 2 & 1.8 \\
\hline $\mathrm{B} * 08$ & 7 & 2.5 & 2 & 1.8 \\
\hline $\mathrm{B} * 13$ & 2 & 0.7 & 1 & 0.9 \\
\hline$B * 14$ & 5 & 1.7 & 1 & 0.9 \\
\hline B*15 & 31 & 10.6 & 7 & 6.1 \\
\hline B*18 & 2 & 0.7 & 1 & 0.9 \\
\hline$B * 22$ & 1 & 0.3 & 0 & 0.0 \\
\hline$B * 27$ & 2 & 0.7 & 1 & 0.9 \\
\hline $\mathrm{B} * 35$ & 102 & 34.5 & 44 & 38.6 \\
\hline$B * 37$ & 1 & 0.3 & 0 & 0.0 \\
\hline$B * 38$ & 4 & 1.4 & 2 & 1.8 \\
\hline$B * 39$ & 14 & 4.7 & 7 & 6.1 \\
\hline$B * 40$ & 31 & $10.6^{b}$ & 4 & 3.5 \\
\hline$B * 41$ & 0 & 0.0 & 1 & 0.9 \\
\hline
\end{tabular}




\begin{tabular}{|lcccc|}
\hline $\mathrm{B}^{*} 42$ & 1 & 0.3 & 0 & 0.0 \\
$\mathrm{~B} * 44$ & 18 & 6.1 & 4 & 3.5 \\
$\mathrm{~B} * 45$ & 3 & 1.0 & 1 & 0.9 \\
$\mathrm{~B} * 46$ & 1 & 0.3 & 0 & 0.0 \\
$\mathrm{~B} * 47$ & 2 & 0.7 & 0 & 0.0 \\
$\mathrm{~B} * 48$ & 24 & 8.2 & 7 & 6.1 \\
$\mathrm{~B} * 49$ & 2 & 0.7 & 2 & 1.8 \\
$\mathrm{~B}^{*} 50$ & 2 & 0.7 & 2 & 1.8 \\
$\mathrm{~B} * 51$ & 24 & 8.2 & 16 & 14.0 \\
$\mathrm{~B}^{*} 52$ & 2 & 0.7 & 1 & 0.9 \\
$\mathrm{~B} * 53$ & 2 & 0.7 & 0 & 0.0 \\
$\mathrm{~B}^{*} 55$ & 2 & 0.7 & 0 & 0.0 \\
$\mathrm{~B} * 57$ & 1 & 0.3 & 1 & 0.9 \\
$\mathrm{~B} * 58$ & 1 & 0.3 & 0 & 0.0 \\
\hline
\end{tabular}

$\mathrm{AF}=$ Allele frequency

a Statistical significance determined by a Chi-square test. HLA-Cw*01allele frequency higher in Peruvian mestizos compared to Bolivian mestizos (Chi-sq= $4.87 \mathrm{p}<0.05$ )

${ }^{\mathrm{b}}$ Statistical significance determined by a Chi-square test. HLA-B*40 allele frequency higher in Peruvian mestizos compared to Bolivian mestizos (Chi-sq= $7.56 \mathrm{p}<0.01$ )

Tabel 2 - HLA Class II allele frequencies in Peruvian (Arequipa) vs. Bolivian mestizos.

\begin{tabular}{|lcccc|}
\hline & \multicolumn{2}{c}{$\begin{array}{c}\text { Peruvian mestizo } \\
(\mathrm{n}=148)\end{array}$} & \multicolumn{2}{c|}{$\begin{array}{c}\text { Bolivian mestizo } \\
(\mathrm{n}=57)\end{array}$} \\
& \multicolumn{2}{c}{296 alleles } & \multicolumn{2}{c|}{114 alleles } \\
\hline HLA class II alleles & $\mathrm{n}$ & AF $(\%)$ & $\mathrm{n}$ & AF (\%) \\
DRB1*01 & 4 & 1.4 & 2 & 1.8 \\
DRB1*02 & 16 & 5.1 & 0 & 0.0 \\
DRB1*0301 & 17 & 5.4 & 3 & 2.6 \\
DRB1*0401 & 55 & 17.9 & 31 & 27.2 \\
& 14 & 4.6 & 5 & 4.4 \\
DRB1*08 & 58 & 18.8 & 29 & 25.4 \\
DRB1*0901 & 54 & 17.6 & 12 & 10.5 \\
DRB1*1001 & 2 & 0.7 & 1 & 0.9 \\
DRB1*1101 & 15 & $4.9 \mathrm{a}$ & 1 & $\mathbf{0 . 9}$ \\
DRB1*13 & 19 & 6.3 & 7 & 6.1 \\
DRB1*1402 & 42 & 13.8 & 14 & 12.3 \\
DRB1*1501 & 0 & 0.0 & 1 & 0.9 \\
DRB1*1602 & 0 & 0.0 & 8 & 7.0 \\
& & & & \\
DQB1*0201 & 9 & 6.9 & 7 & 6.1 \\
DQB1*0301 & 36 & 27.7 & 24 & 21.1 \\
DQB1*0302 & 28 & 21.5 & 33 & 28.9 \\
DQB1*0303 & 23 & 17.7 & 11 & 9.6 \\
DQB1*0304 & 0 & 0.0 & 1 & 0.9 \\
DQB1*0401 & 11 & 8.5 & 0 & 0.0 \\
\hline
\end{tabular}




\begin{tabular}{|lllll|}
\hline DQB1*0402 & 6 & $\mathbf{4 . 6}$ & 29 & $\mathbf{2 5 . 4}$ \\
DQB1*0501 & 5 & 3.8 & 3 & 2.6 \\
DQB1*0503 & 1 & 0.8 & 0 & 0.0 \\
DQB1*0601 & 2 & 1.5 & 0 & 0.0 \\
DQB1*0602 & 2 & 1.5 & 2 & 1.8 \\
DQB1*0603 & 1 & 0.8 & 2 & 1.8 \\
DQB1*0604 & 6 & 4.6 & 2 & 1.8 \\
\hline
\end{tabular}

$\mathrm{AF}=$ Allele frequency

${ }^{\text {a }}$ Statistical significance determined by a Chi-square test. HLA-DRB $1 * 1101$ allele frequency higher in Peruvian mestizos compared to Bolivian mestizos (Chi-sq= $5.12 \mathrm{p}<0.05$ )

${ }^{\mathrm{b}}$ Statistical significance determined by a Chi-square test. HLA-DQB $1 * 0402$ allele frequency higher in Bolivian mestizos compared to Peruvian mestizos (Chi-sq $=47.3 \mathrm{p}<0.0001$ )

Table 3 - HLA Class II allele frequencies in Peruvian (Lima) vs. Bolivian mestizos.

\begin{tabular}{|c|c|c|c|c|}
\hline \multirow[b]{2}{*}{ HLA Class II alleles } & \multicolumn{2}{|c|}{$\begin{array}{l}\text { Peruvian mestizo } \\
(\mathrm{n}=65) \\
130 \text { alleles }\end{array}$} & \multicolumn{2}{|c|}{$\begin{array}{c}\text { Bolivian mestizo } \\
(\mathrm{n}=57) \\
114 \text { alleles }\end{array}$} \\
\hline & $\mathrm{n}$ & $\mathrm{AF}(\%)$ & $\mathrm{n}$ & $\mathrm{AF}(\%)$ \\
\hline DRB $1 * 0101$ & 3 & 2.3 & 2 & 1.8 \\
\hline DRB $1 * 0102$ & 2 & 1.5 & 0 & 0.0 \\
\hline DRB $1 * 0301$ & 3 & 2.3 & 3 & 2.6 \\
\hline DRB $1 * 0302$ & 1 & 0.8 & 0 & 0.0 \\
\hline DRB $1 * 04$ & 40 & 30.8 & 31 & 27.2 \\
\hline DRB $1 * 0701$ & 3 & 2.3 & 5 & 4.4 \\
\hline DRB $1 * 08$ & 18 & 13.8 & 29 & 25.4 \\
\hline DRB $1 * 0901$ & 18 & 13.8 & 12 & 10.5 \\
\hline DRB $1 * 1001$ & 0 & 0.0 & 1 & 0.9 \\
\hline DRB $1 * 1101$ & 6 & 4.6 & 1 & 0.9 \\
\hline DRB $1 * 1103$ & 2 & 1.5 & 0 & 0.0 \\
\hline DRB $1 * 1104$ & 2 & 1.5 & 0 & 0.0 \\
\hline DRB $1 * 1301$ & 0 & 0.0 & 2 & 1.8 \\
\hline DRB1*1302 & 7 & $5.4^{\mathrm{a}}$ & 1 & 0.9 \\
\hline DRB $1 * 1303$ & 1 & 0.8 & 2 & 1.8 \\
\hline DRB $1 * 1304$ & 3 & 2.3 & 0 & 0.0 \\
\hline $\mathrm{DRB} 1 * 1305$ & 1 & 0.8 & 1 & 0.9 \\
\hline $\mathrm{DRB} 1 * 1320 / 29$ & 0 & 0.0 & 1 & 0.9 \\
\hline DRB1*1402 & 11 & 8.5 & 14 & 12.3 \\
\hline DR2 & 9 & 6.9 & 9 & 7.9 \\
\hline
\end{tabular}




\begin{tabular}{|lcccl|}
\hline DQB1*0201 & 9 & 6.9 & 7 & 6.1 \\
DQB1*0301 & 36 & 27.7 & 24 & 21.1 \\
DQB1*0302 & 28 & 21.5 & 33 & 28.9 \\
DQB1*0303 & 23 & 17.7 & 11 & 9.6 \\
DQB1 0304 & 0 & 0.0 & 1 & 0.9 \\
DQB1*0401 & 11 & 8.5 & 0 & 0.0 \\
DQB1*0402 & 6 & 4.6 & 29 & 25.4 \\
DQB1*0501 & 5 & 3.8 & 3 & 2.6 \\
DQB1*0503 & 1 & 0.8 & 0 & 0.0 \\
DQB1*0601 & 2 & 1.5 & 0 & 0.0 \\
DQB1*0602 & 2 & 1.5 & 2 & 1.8 \\
DQB1*0603 & 1 & 0.8 & 2 & 1.8 \\
DQB1*0604 & 6 & 4.6 & 2 & 1.8 \\
\hline
\end{tabular}

$\mathrm{AF}=$ Allele frequency

${ }^{\text {a }}$ Statistical significance determined by a Chi-square test. HLA-DRB $1 * 1302$ allele frequency higher in Peruvian mestizos compared to Bolivian mestizos (Chi-sq $=3,8 \mathrm{p}=0,05)$

share a "Spanish Caucasoid genetic pool" (Serrano-Rios et al., 1999), HLA differences found here might be due to the fact that our mestizo population came from subjects participating in a field study, while those reported in the literature from Peru are composed mainly of people attending social security Hospitals, with probably less rural traits and more white (Caucasian) admixture, and/or a higher grade of admixture with Andean ethnic groups in the mestizos from Bolivia. It is interesting to see for example absence of DRB1*1602 (a well known Amerindian allele) in the group of Peruvian mestizos reported form Arequipa (de Pablo et al., 2000) (see Table 2).

Ethnic distribution in Bolivia comprises mestizo (Mixed) almost 38\%, followed by a significant percentage of Quechua (34\%) and Aymara (22\%) populations, and other ethnicities found in the lowland (1,5\%). The study of whether or not similar differences between other ethnic groups present in both countries occur is warranted. A study of ethnic identity at a genetic level of Quechua Andean populations of Bolivia and Peru is planned in the near future by this laboratory.

The MHC contributes significantly to the genetics human disease, as MHC contribute to the genetic susceptibility to autoimmunity, cancer and infectious diseases (Howard et al., 1999). Correlations of diseases with HLA antigen frequency have been the subject of considerably research, and HLA is found to be associated with several diseases (Bryant, 1994). Particular HLA alleles and haplotypes found in Hispanic groups and Mestizo populations have been reported associated with clinical (Castro et al., 1996, Gil-Carrasco et al., 1999), infectious (Fujiyoshi et al., 1995; Maciag et al., 2000; Silva et al., 1999; Apple et al., 1994; Apple et al., 1995) autoimmune (GarcíaGonzález et al., 1999) or metabolic diseases (Serrano-Ríos et al., 1999; Seclen et al., 1996). I recently made a preliminary report on a particular Amerindian allele conferring risk to infection with the human papillomavirus, responsible of causing cancer of the uterine cervix in women (Cervantes et al., 2002). 
The importance of our findings may have an impact regarding efficacies of modern forms of immunization by means of DNA vaccines (which interact with the HLA-class molecules) (Mc Donell \& Askari, 1996), as well as in the identification of groups at risk for certain medical conditions in Andean populations.

\section{References cited}

APPLE, R. J., ERLICH, H. A., KLITZ, W., MANOS, M. M., BECKER, T. M., WHEELER \& C. M., 1994 - HLA DR-DQ associations with cervical carcinoma show papillomavirustype specificity. Nature Genetics, 6(2):157-162.

APPLE, R. J., BECKER, T. M., WHEELER, C. M. \& ERLICH, H. A., 1995 - Comparison of human leukocyte antigen DR-DQ disease associations found with cervical dysplasia and invasive cervical carcinoma. Journal of the National Cancer Institute, 87(6): 427-436.

APPLE, R. J. \& ERLICH, H., A., 1996 - HLA class II genes: structure and diversity. In: HLA and MHC: genes, molecules and function (M. Browning \& A. McMichael Eds.): 91-112; BIOS Scientific Publishers Limited.

BRYANT, N. J., 1994 - The HLA system in An Introduction to Immunohematology: 256-273; W.B. Saunders Company.

BUGAWAN, T. L., APPLE, R., ERLICH, H. A., 1994 - A method for typing polymorphism at the HLA-A locus using PCR amplification and immobilized oligonucleotide probes. Tissue Antigens, 44(3): 137-147.

CASTRO, F., ACEVEDO, E., CIUSANi, E., ANGUlo, J. A., WOllheim, F. A. \& SANDBERG-WOLLHEIM, M., 2001 - Tumour necrosis factor microsatellites and HLA-DRB1*, HLA-DQA1*, and HLA-DQB1* alleles in Peruvian patients with rheumatoid arthritis. Annals of the Rheumatic Diseases, 60(8): 791-795.

CERVANTES, J., HURTADO, L. V., LEMA, C., ANDRADE, R., HURTADO, L., YASHIKI, S., FUJIYOSHI, T. \& SONODA, S., 2002 - HLA-DRB1*1602 allele association with HPV infection in Bolivian women. Tissue Antigens, 59(2): 122 P32.12.

DE PABLO, R., BERAUN, Y., NIETO, A., CALZADA, J. E., REMENTERIA, M. C., SANZ, L., LOPEZ-NEVOT, M. A. \& MARTIN, J., 2000 - HLA class I and class II allele distribution in the Peruvian population. Tissue Antigens, 56(6): 507-514.

FUJIYOSHI, T., YASHIKI, S., FUJIYAMA, C., KUWAYAMA, M., MIYASHITA, H., OHNISHI, H., BLANK, M., ZANINOVIC, V., BLANK, A., CARTIER, L., et al., 1995 - Ethnic segregation of HTLV-I and HTLV-II carriers among South American native Indians. International Journal of Cancer, 63(4): 510-515.

GARCÍA-GONZÁLEZ, E., CASTRO-LLAMAS, J., KARCHMER, S., ZÚNIGA, J., DE OCA, D. M., AMBAZ, M., BOLANOS, R. \& GRANADOS, J., 1999 - Class II major histocompatibility complex typing across the ethnic barrier in pemphigoid gestationis. A study in Mexicans. International Journal of Dermatology, 38(1): 46-51.

GIL-CARRASCO, F., VARGAS-ALARCÓN, G., ZÚNIGA, J., TINAJERO-CASTANEDA, O., HERNÁNDEZ-MARTÍNEZ, B., HERNÁNDEZ-PACHECO, G., RODRÍGUEZREYNA, T. S., HESIQUIO, R., GAMBOA, R., GRANADOS, J., 1999 - HLA-DRB and HLA-DQB loci in the genetic susceptibility to develop glaucoma in Mexicans. American Journal of Ophthalmology, 128(3): 297-300.

HOWARD, M. C., SPACK, E. G., CHOUDHURY, K., GRETEN, T. F., SCHNECK, J.P., 1999 MHC-based diagnostics and therapeutics - clinical applications for disease-linked genes. Immunology Today, 20(4): 161-165.

International Histocompatibility Working Group (IHWG) Anthropology Human / Genetic Diversity Component. 2002 Anthropology Demographic and Background Data Entry Form. Ethnicity Codes Tables.http://www.ihwg.org/shared/database.htm\#Anthropology 
KATAHIRA, Y., YASHIKI, S., FUJIYOSHI, T., NOMURA, K., TARA, M., MORI, M., SETOYAMA, M., KANZAKI, T., SHIDA, H. \& SONODA, S., 1995 - In vitro Induction of Cytotoxic T Lymphocytes against HTLV-I infected T-Cells from Adult T-Cell Leukemia Patients, Asymptomatic HTLV-I Carriers and seronegative Healhty donors. Japanese Journal of Cancer Research, 86: 21-27.

MACIAG, P. C., SCHLECHT, N. F., SOUZA, P. S., FRANCO, E. L., VILLA, L. L. \& PETZLERLER, M. L., 2000 - Major histocompatibility complex class II polymorphisms and risk of cervical cancer and human papillomavirus infection in Brazilian women. Cancer Epidemiol Biomarkers and Prevention, 9(11): 1183-1191.

MCDONELL, W. M. \& ASKARI, F. K., 1996 - Molecular Medicine. DNA Vaccines. The New England Journal of Medicine, 334(1): 42-45.

MOSS, D. J. \& KHANNA, R., 1999 - Major histocompatibility complex: from genes to function. Immunology Today, 20(4): 165-167.

SECLEN, S., ROJAS GABRIELLI, M. I., NÚNEZCHAVEZ, O., MILLONES, B. \& VALDIVIA, H., 1996 - Registro de 10 años de incidencia (1985-1994) de diabetes mellitus insulinodependiente tipo I en poblacion mestiza infantil peruana y estudio molecular (DNA) de alelos y genotipos diabetogénicos HLA-DR, DQ*A1, DQ*B1: 12-21; Premio Nacional de Investigación Hipolito Unánue. Lima: Academia Nacional Peruana de Medicina.

SILVA, B., VARGAS-ALARCÓN, G., ZÚNIGA-RAMOS, J., RODRÍGUEZ-REYNA, T. S., HERNÁNDEZ-MARTÍNEZ, B., OSNAYA, N., KOFMAN, S., TORRES-LOBATON, A. \& GRANADOS, J., 1999 - Genetic features of Mexican women predisposing to cancer of the uterine cervix. Human Pathology, 30(6): 626-628.

SERRANO-RÍOS, M., GODAY, A. \& MARTÍNEZ LARRAD, T., 1999 - Migrant populations and the incidence of type 1 diabetes mellitus: an overview of the literature with a focus on the Spanish-heritage countries in Latin America. Diabetes Metabolism Research and Reviews, 15(2): 113-132. 